\title{
THREE STRATEGIES OF PROFILING EVENTS IN CAUSATIVE CONSTRUCTION WITH PREFIX PA- IN DHAO
}

\author{
Jermy I. Balukh \\ STIBA Cakrawala Nusantara Kupang \\ jbalukh@yahoo.com.au
}

\begin{abstract}
This paper investigates causative constructions which involves the prefix $p a$ - in Dhao.. Dhao is a language spoken by about 3000 people on Ndao Island, Eastern Indonesia. The use of $p a$ - results in three different constructions. First, a construction with a single verbal predicate in which $p a$ - is fused with the base verb expressing the cause and caused events. Second, the $p a$-derived verb requires a lexical verb to precede it resulting in a SVC. Thus, the events profiled are arranged into separate components. Third, the construction is periphrastic, where the $p a$-derived verb appears in the subordinate clause designating result state of the causee, while the causation is expressed by a lexical verb in the main clause. These three different strategies are employed to express different events profiled in the causativized construction.
\end{abstract}

Keywords: causative, events, construction, serial verbs, periphrastic

\begin{abstract}
Abstrak
Makalah ini mengkaji tentang konstruksi kausatif yang menggunakan prefix pa-dalam bahasa Dhao. Bahasa Dhao dituturkan oleh sekitar 3000 orang di Pulau Ndao, Indonesia Timur. Penggunaan prefiks pa- menghasilkan tiga konstruksi yang berbeda. Pertama, konstruksi berpredikat verbal tunggal dengan prefix pa- yang menyatu dengan verba dasar untuk mengungkapkan sebab dan peristiwa yang disebabkan. Kedua, peristiwa yang digambarkan dipisahkan dengan komponen yang berbeda. Ketiga, konstruksi perifrastik, dengan verba hasil dari derivasi prefix pa- yang muncul di anak klausa untuk mengungkapkan hasil dari yang tersebab, sedangkan sebab diungkapkan dengan sebuah verba leksikal pada induk klausa. Tiga strategi yang berbeda ini dipakai untuk mengungkapkan peristiwa yang berbeda yang digambarkan dalam konstruksi yang dikausatifkan.
\end{abstract}

Kata kunci: kausatif, peristiwa, konstruksi, verba rangkap, perifrastik

\section{INTRODUCTION}

Dhao language (ISO 639-3: nfa) is spoken by about 3,000 people mainly on Ndao Island, a small island westward of Rote Island in the East Nusa Tenggara Province of Indonesia. A number of Dhao speakers are now living on Rote, Timor, and Flores Islands. Dhao is genetically classified into Sumba-Hawu subgroup within Central Malayo-Polynesian (CMP) of Austronesian language family and as such resembles the languages of Sumba and Sawu (Grimes, 2010; Blust, 2013). However, Dhao has no direct contact with Hawu. Instead, it has an intense contact with its neighbor, Rote, due to geographical proximity and formal government administration (Balukh, 2015a). Jonker (1903) considered Dhao as a dialect of Hawu, but later Walker (1982) and Grimes (2010) have argued that Dhao is a separate language from Hawu, 
although they have some lexical and phonological similarities. One salient difference between the two languages is the basic word order. While Hawu is a VS(O) language, Dhao is an SV(O) language. Another difference is the pronominal system. Hawu has a simple pronominal system, that is Hawu only has full personal pronouns, but Dhao has a more complex system, i.e., it has full and reduced pronouns, as well as clitics and affixes (Balukh, 2015a). Dhao full pronouns are similar to those in Hawu, but the clitics and affixes are similar to those in Rote. Like other languages in Eastern Indonesia, Dhao also has serial verb constructions (SVC) which are productive. Morphologically, Dhao combines isolation and concatenation system in which some markers stand independently as individual words and some other markers are attached to their hosts, but still segmentable.

This paper investigates causative constructions in Dhao, which involves the prefix $p a-$, the only derivational affix in Dhao. Before discussing how events are profiled in the causativized constructions, I briefly introduce the basic clause structure in Dhao. The basic word order in Dhao is SVO, as illustrated by the transitive construction in (1) below. There is no strict (morpho)syntactic difference between word categories, such as nouns and verbs, and between verbs and adjectives (Balukh, 2015b). The salient feature of verbs is the crossreference affixes, which are confined only to nine verbs (Balukh, 2015a; Grimes, 2010). One example is demonstrated by the prefix $k$ - in (1) that is co-indexed with the subject ja'a '1SG'.

$$
\begin{array}{ll}
j a^{\prime} a_{\mathrm{i}} \quad k_{\mathrm{i}}-u^{\prime} a & k a u \\
1 \mathrm{SG} \quad 1 \mathrm{SG}-\mathrm{eat} & \text { rice } \\
\text { 'I eat rice' } &
\end{array}
$$

This paper discusses three strategies of profiling events in causative constructions brought by the prefix $p a$ - in Dhao. The three strategies are expressed within three types of constructions; causative events expressed by single derived $p a$-verb, SVCs, and periphrastic constructions.

The data in this paper came from both a corpus and elicitation. The corpus consisted of over 80 transcribed natural texts and 1,800 lexical items in the lexicon database. The texts were transcribed in ELAN software and interlinearized in Toolbox software. These two software helped with a quick concordance or multiple searches to find the items that take the prefix $p a-$. In addition, the collocation of the target forms could also be easily found. Many gaps in the data were filled by oral elicitation or deep interview with two native speakers. They were asked to create contexts in which the target sentences with particular verbs are used. The elicitation was done based on texts used in the corpus. Other extra contexts may be created whenever it is relevant. The grammaticality of the sentences either found in the corpus or created during the elicitation was judged by the native speakers. Normally, they found some sentences straightforwardly grammatical, but some are ungrammatical. There is always the case that some sentences are considered grammatically correct, but are rarely used in the real world. The analysis applies three tests: first, the syntactic function of prototypical verbs and adjectives; second, different positions of noun phrases (NPs) that function as the undergoer; and third, the use of negation in the given construction. 


\section{PREFIX pa- IN DHAO}

Before discussing the semantic constraints and syntactic construction of causative in Dhao, it is important to present firstly the bases of the prefix $p a$ - and to describe briefly how it works. The prefix $p a$ - derives not only verbs from either verbal or non-verbal bases, but it also derives adverbs from adjectives (Balukh, 2016). In terms of valency changing operation, the prefix padoes not only increase valency (causative) but it also decreases valency (reciprocal), as well as re-arrange the valency of verbs (Balukh, to appear). In order to have a causative meaning, the prefix $p a$ - is attached to nouns, verbs, adjectives, and numerals. The derived forms with the prefix $p a$ - resulting in bivalent and trivalent verbs semantically denote causative meaning. Meanwhile, the derived monovalent verbs designate either reciprocal, mutual, or resultative meanings respectively. Intensity meaning denoted by the prefix $p a-c a n$ be derived from either monovalent or bivalent verbs. Other specific meanings can also be encoded by prefixing $p a-$. The bases and meanings of prefix $p a$ - in Dhao are listed in Table 1 below.

Table 1. Bases and Meanings of prefix pa-

\begin{tabular}{lll}
\hline Meanings & Base forms & Derived forms \\
\hline Causative & $\begin{array}{l}\text { Monovalent verbs } \\
\text { Bivalent verbs } \\
\text { Ambivalent verbs } \\
\text { Adjectives }\end{array}$ & Bivalent verbs \\
\cline { 2 - 3 } & Nouns & Bi/trivalent verbs \\
\cline { 2 - 3 } & Numerals & Bivalent \\
\hline Manipulative & Bivalent verbs & Trivalent verbs \\
\cline { 2 - 3 } & Monovalent verbs & Bivalent verbs \\
\hline Intensity & Monovalent verbs & Mono/bivalent verbs \\
& Bivalent verbs & \\
\hline Simultaneity & Monovalent verbs & Monovalent verbs \\
\cline { 2 - 3 } & Bivalent verbs & Bivalent verbs \\
\hline Reciprocal & Bivalent verbs & Monovalent verbs \\
\hline Resultative & Monovalent verbs & Monovalent verbs \\
\hline Habitual & Nouns & Monovalent verbs \\
\hline Durative & Nouns & Adverbs \\
\hline Factitive & Nouns & Monovalent verbs \\
\hline Other & Monovalent verbs & Mono/bivalent verbs \\
& Bivalent verbs & \\
\cline { 2 - 3 } & Nouns & Nouns \\
\hline
\end{tabular}

The illustrations of some constructions involving the prefix $p a$ - with various meanings are presented below. The data in (2) shows a causative meaning. The verb root is a monovalent verb manahu 'to.fall' which denotes a physical action; that is, someone is dropping from a high position. The prefix $p a$ - brings causative meaning, in that construction the actor, $r a$ ' $3 \mathrm{PL}$ ' is causing the undergoer bhèni èèna 'the woman' to fall. In (3), the prefix $p a$-is attached to a bivalent verb tenge 'to.look.for'. When prefixed with $p a$-, it denotes the meaning 'to look for something intentionally and intensively'. In this case, the speaker is asking people to look for someone intensively. In (4), the prefix $p a$ - is attached to a bivalent verb, liku 'to.hug', which denotes a reciprocal meaning; that is, they hug each other at the same time. The resultative 
meaning brought by the prefix $p a$ - is shown in (5), which is attached to a monovalent verb. The derived verb in this case denotes a resulting state of an inanimate subject, boto 'bottle' in which the cause of the event of standing is unknown.

(2)

\section{Causative}

ra

3PL

pa-manahu

bhèni èèna

'They cause the woman to fall'

woman DIST.SG

(3)

$\begin{array}{lllll}\text { Intensity } & & & \\ \grave{e} d h i & \text { pa-tenge } & k u & \text { dhèu } & \text { la } \\ \text { 1PL.in } & \text { INTS-to.look.for } & \text { tag } & \text { person } & \text { PART }\end{array}$

(4) Reciprocal

dua rèngu pa-liku

two 3PL RECP-to.hug

'They hug each other'

(5)

Resultative
boto èci dhu pa-titu $\quad$ ètu dedha hadhu
bottle one REL RES-to.stand LOC above Stone
'a bottle is standing on the stone'

As seen in the examples above, the prefix $p a$ - does not only increase the valency of the verb, like the causative construction in (2), but it also decreases the valency of the verb, like the reciprocal construction in (4). Meanwhile, in the other examples, the prefix $p a$ - simply adds meaning to the constructions, and maintains the valency of the verb.

\section{CAUSATIVE CONSTRUCTIONS IN DHAO}

Causative meaning is commonly expressed by verbal constructions profiling an action that brings about a particular process leading to a change of state of an entity (Shibatani \& Pardeshi, 2001). This phenomenon refers to a situation that is cross-linguistically termed causative situation in which two interrelated events are involved; the causing event and the caused event (Shibatani, 1976; Kulikov, 2001). Formally, causative construction may be expressed by means of morphological, syntactic, or lexical construction (Kulikov, 2001). In addition, serial verb constructions (SVCs) may also express causative meanings (Dixon, 2012).

In Dhao, causative meaning is brought by the prefix $p a$-. The examples of causative $p a$ with various bases are presented as follows: a monovalent verb in (6), noun in (7), number in (8), and adjective in (9). In (6), the base verb madhe 'to die' semantically denotes the state of the entity, kahibi èena 'that goat'. When it is prefixed with $p a$-, the morphologically complex verb denotes an action that causes a change of state, namely from being alive into being not alive or dead. This implies that the actor rèngu '3PL' acts in a particular manner resulting in a situation in which the undergoer kahibi èena 'that goat' is dead. In this respect, the prefix pa- is expressing the causation or the causing event, whereas the verbal base madhe 'to die' is expressing the result state. Here, the prefix and the verbal base are integrated in a complex form to express a causative meaning. In (7), the derived form paèi 'to solder, to melt' profiles an event that requires the doer (actor) of the soldering event and the entity (undergoer) to be soldered. The undergoer is directly affected in that the actor causes the undergoer melted with a 
water-like material. In (8), the derived verb paèci denotes the meaning 'cause to become one, to unite' (for numeral base, the prefix $p a$ - is confined to the cardinal number èci 'one' and the fraction ca malore 'a half'). The sentence implies that someone has intention to get together with other people within a particular group. Furthermore, in (9), the derived verb pa-ana.iiki 'to make sth. small' designates that the subject èdhi '1PL.in' does a particular action, which causes the $\log$ to be small in size. Like monovalent verbal bases, the prefix integrates with the base to indicate a process leading to the change of state of the entity. The difference is that this construction obligatorily requires an action verb, such as sai 'to chop' to express the causation. Thus, it results in a SVC (Balukh, 2015b). This will be discussed further below.

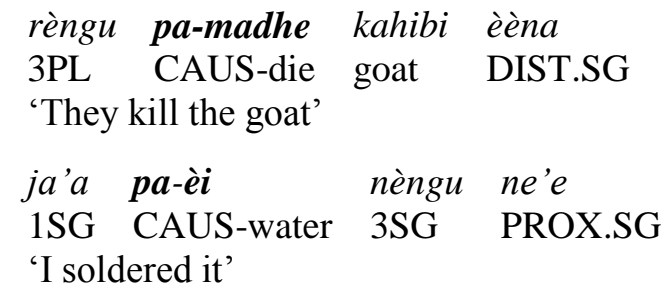

It has been explicated previously that the causative verbs bring about a particular process resulting in a change of state of an entity. In Dhao, this does not automatically imply, however, that the derived verbs syntactically equal to underived verbs in terms of predicate positions. It is because the syntactic construction of the derived causative verbs is controlled by the semantics of the verbal bases attached to the prefix $p a$-. In order to understand how such a construction as such work in Dhao, it is important to present the scale between prototypical verbs and prototypical adjectives in Dhao in (10) below (Balukh, 2016).

\begin{tabular}{|c|c|c|c|c|}
\hline \multirow[t]{5}{*}{ Predicate only } & \multirow[t]{5}{*}{$\mathrm{A}$} & kako & 'to walk' & \multirow{5}{*}{$\begin{array}{c}\text { Verb } \\
\end{array}$} \\
\hline & & tangi & 'to cry' & \\
\hline & & muri & 'to grow' & \\
\hline & & mèu & 'be clean' & \\
\hline & & hera & 'be dirty' & \\
\hline \multirow{4}{*}{ Predicate $\&$ modifier } & \multirow[t]{2}{*}{$\mathrm{B}$} & pèda & 'be sick' & \\
\hline & & madhe & 'be dead, die' & \\
\hline & \multirow[t]{2}{*}{$\mathrm{C}$} & manii & 'thin' & \\
\hline & & mèdi & 'black' & \\
\hline \multirow[t]{2}{*}{ N-modifier only } & \multirow[t]{2}{*}{$\mathrm{D}$} & (ana) iiki & 'small' & \multirow{2}{*}{ Adjective } \\
\hline & & (mone) aae & 'great, big' & \\
\hline
\end{tabular}

In (10) above, the first column indicates the syntactic position of the lexemes in the list, while the second column indicates the groups of the lexemes based on their syntactic position. 
The third and fourth columns are the list of lexemes and their glosses respectively. The last column shows the scale of verbs and adjectives in Dhao. The prototypical verbs syntactically fill predicate positions. In this case, only the lexemes in group A apply. Contrastively, the lexemes in group D can only become noun modifiers and never fill predicate slots in their bare forms, which imply that they are prototypical adjectives. There are intermediate groups, i.e., the group $\mathrm{B}$ and $\mathrm{C}$, that can behave both like verbs in group A and adjectives in group D. It is because of the semantics of the lexemes in those groups express state. In terms of the causative meaning brought by the prefix $p a$-, the verb-like lexemes have the prefix $p a$-integrated with the base to express the causing and the caused event, whereas the adjective-like lexemes have the causing event expressed separately with a specific action verb. The lexemes in group A and B are classified into verbs because the prefix $p a$ - and the verb are simply integrated, whereas group $\mathrm{C}$ and $\mathrm{D}$ are classified into adjectives because the integration of the prefix $p a$-requires another verb to express the causation. Therefore, in this paper, the causative constructions are expressed within three strategies. First, the verbs and the prefix $p a$ - are simply integrated, so the predicate has only a single verb. Second, the derived verbs with $p a$ - require another action verb to express the causation, resulting in an SVC. Third, the $p a$ - derived verb occurs in a subordinate clause, whereas the causation is expressed by a lexical verb in the main clause, resulting in a periphrastic construction. Each of the three strategies is discussed below.

\section{Single Verbal Predication}

In single verbal predication, the prefix $p a$ - is simply attached to the base verbs to have causative meaning. The verbs in this case of course should be monovalent verbs. However, as stated in the list in (10) above, the verbs should be prototypical verbs in the sense that they are mainly actororiented verbs in that they do not require any extra verb to express the causation. The prefix pais fused with the verbal base. The example (11) below demonstrates that the verbal base kako 'to walk' is an action monovalent verb. It is an actor-oriented verb that requires an actor participant. It is simply prefixed with $p a$ - to denote the causative meaning 'to run sth.' The causation brought by the prefix $p a$ - is integrated with the caused event expressed by a single morphologically complex verb. Such a verb alone occurs in the predicate position.

$$
\begin{array}{lllllll}
\text { ji'i } & \text { pa-kako } & \text { kolete } & \text { ètu } & \text { dara } & \text { gereja } & \text { ji'i } \\
\text { 1PL.ex } & \text { CAUS-walk } & \text { offering } & \text { LOC } & \text { inside } & \text { church(IND) } & \text { 1PL.ex }
\end{array}
$$

'We run offerings in our church'

Another example is given in (12)a that has the state-verbal base hera 'be.dirty'. The prefix $p a$ - and the verbal base are fused to express the causative meaning. When the generic verb tao 'make' is added to express the causation specifically, the construction is judged ungrammatical. This implies that although hera 'be dirty' semantically denotes state, but syntactically it is a verb, just like kako 'to walk'. The fusion of the prefix and the base signals that the causing event and result state are integrated within a single complex causative verb. The list of action verbs taking the prefix $p a$ - is given in (13).
a. nèngu pa-hera
èmu èèna
3SG CAUS-dirty house DIST.SG
'He makes that house dirty' 


\section{b. nèngu (*tao) pa-hera èmu èèna \\ 3SG (make) CAUS-be.dirty house DIST.SG}

'He makes the house dirty'

(13) Action monovalent verb bases for $p a-$

$\begin{array}{llll}\text { bèbhe } & \text { 'to fall' } & \text { pa-babhe } & \text { 'to fell X' } \\ \text { bodho } & \text { 'to exit' } & \begin{array}{l}\text { pa-bodho } \\ \text { pa-cèna }\end{array} & \text { 'cause X to exit' } \\ \text { cèna } & \text { 'to sink' } & \text { 'cause X to sink' } \\ \text { dha'u } & \text { 'to go down' } & \begin{array}{l}\text { pa-dha'u } \\ \text { ga-guri }\end{array} & \text { 'make go down' } \\ \text { guri } & \text { 'to collapse' } & \text { 'make X collapse' } \\ \text { hae } & \text { 'to flow' } & \text { pa-hae } & \text { 'make X flow' } \\ \text { kabhui } & \text { 'to fall' } & \text { pa-kabhui } & \text { 'to fell (fruit)' } \\ \text { kako } & \text { 'to walk' } & \text { pa-kako } & \text { 'to run X' } \\ \text { kèdi } & \text { 'to get.up' } & \text { pa-kèdi } & \text { 'to wake up X' } \\ \text { manahu } & \text { 'to fall' } & \text { pa-manahu } & \text { 'cause X to fall' }\end{array}$

The example (6) above is presented again in (14) below with its intransitive counterpart in (14)a. The verbal base madhe 'die' in this case is an undergoer-oriented verb. This verb is in the intermediate position within the scale in (10) above, which indicates that it may take the prefix $p a$ - and occurs in a single predicate or in a SVC. As seen in (14)b, the causative meaning is simply expressed by the fusion of the prefix $p a$ - with the verbal base. In this case, the causation is brought by the prefix $p a$ - and the change of state is expressed by the verbal base. The generic verb tao 'make' is optional in (14)c due to the intermediate position of the verb. However, Dhao native speakers prefer not to use the extra lexical verb in this construction. The periphrastic construction, like (14)d, is also possible in that the result state is expressed in a subordinate position, but rarely used by native speakers in real world. List of the monovalent state verbal bases for the causative $p a$ - is given in (15) below.

$$
\begin{aligned}
& \text { a. kahibi èèna madhe le } \\
& \text { goat DIST.SG die } \\
& \text { 'That goat has been dead' }
\end{aligned}
$$

b. rèngu pa-madhe kahibi èèna 3PL CAUS-die goat DIST.SG

'They kill the goat'

c. rèngu (tao) pa-madhe kahibi èèna 3PL (make) CAUS-die goat DIST.SG 'They kill the goat'
d. rèngu tao kahibi èèna pa-madhe 3PL make goat DIST.SG CAUS-die 'They kill the goat'

(15) Monovalent state verbal bases for $p a-$

$\begin{array}{llll}\text { adhu } & \text { 'hard' } & \text { pa-adhu } & \text { 'cause X hard' } \\ \text { bai } & \text { 'swollen' } & \text { pa-bai } & \text { 'cause X swollen' } \\ \text { bani } & \text { 'brave' } & \text { pa-bani } & \text { 'cause X brave' } \\ \text { bèdhu } & \text { 'blind' } & \text { pa-bèdhu } & \text { 'cause X blind' } \\ \text { bhaka } & \text { 'blunt' } & \text { pa-bhaka } & \text { 'cause X blunt' }\end{array}$




$\begin{array}{llll}\text { èra } & \text { 'strong' } & \text { pa-èra } & \text { 'cause X strong' } \\ \text { j'èra } & \text { 'suffer' } & \text { pa-j'èra } & \text { 'cause X suffer' } \\ \text { kèpu } & \text { 'be burnt' } & \text { pa-kèpu } & \text { 'cause X burnt' } \\ \text { madhe } & \text { 'to die' } & \text { pa-madhe } & \text { 'cause X to die' } \\ \text { mèu } & \text { 'be clean' } & \text { pa-mèu } & \text { 'cause X clean' }\end{array}$

\section{Serial Verb Constructions}

Before describing the causative constructions with the prefix $p a$ - that result in serial verb constructions, I briefly introduce the characteristics of serial verb constructions in Dhao. A serial verb construction (SVC) is a monoclausal construction which consists of multiple independent verbs without linking element and without predicate-argument relation between them (Haspelmath, 2016). In Dhao, SVCs involve at most three verbs which must be independent. The constructions share arguments and grammatical properties, such as aspect markers and negators. There is no possibility to add a linking element, such as a coordinator or a subordinator between the serial verbs. Semantically, SVCs in Dhao indicate a complex event involving two or more simultaneous sub-events (Balukh, to appear). SVCs are quite productive in Dhao. Two examples are given in (16) and (17) below. The construction in (16) involves the verb puru 'descend' as V1 immediately followed by the verb mai 'come' as V2. The V2 indicates the directionality of the action denoted by the V1, that is the motion of the action is directed toward the speaker of the utterance. The construction as such can also be intervened by a prepositional phrase indicating location, as illustrated in (16)b. In Dhao, the directional verbs mai 'come' and la- 'go' are productive in case. As seen, the meaning of the construction is fully determined by the meaning of the verbs involved in the SVC. The example in (17) involves two inflected verbs $n a$ ' $a$ 's/he eats' as V1 and $n e ̀ d h i$ 's/he sees' as V2. The two verbs get the same inflectional prefix $n$ - that co-indexes with the subject nèngu '3SG' (Balukh, 2015a). The two verbs also get only one negator, that is boe 'not'. This SVC expresses an experiential meaning in that the V2 emphasizes the experience of the subject doing the intended action.

$$
\begin{aligned}
& \text { a. nèngu puru mai asa rai haha } \\
& \text { 3SG descend come to land below } \\
& \text { 'She came down to the earth' }
\end{aligned}
$$

b. nèngu puru asa rai haha mai
3SG descend to land below come 'She came down to the earth'

$$
\begin{array}{lllll}
\text { nèngu } & \boldsymbol{n} \text {-a'a } & \boldsymbol{n} \text {-èdhi } & \text { boe } & \text { ngaa-ngaa } \\
\text { 3SG } & \text { 3SG-eat } & \text { 3SG-see not } & \text { DUP-what } \\
\text { 'He has never eaten anything' }
\end{array}
$$

When the prefix $p a$ - is employed to mark causative verbs, it may result in SVCs. An example is given in (18) below. The V1 is the generic action verb tao 'make', whereas V2 is the derived verb pabe' $a$ 'make sth. good' whose root is an adjective, $b e$ ' $a$ 'good'. These two verbs are integrated to express the events involved in the causative meaning. When the lexical verb appears, it results in an SVC in that they act together as a single predicate (Aikhenvald, 2006:1; Haspelmath, 2016:292) profiling two interrelated events. 


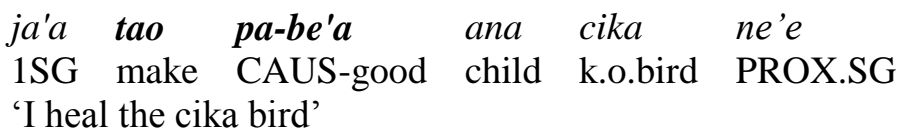

As has been explained previously, the verbs in group B of the scale in (10) above are in intermediate position. They may behave either like verbs or like adjectives. They may optionally take extra action verb to express the causation, as illustrated in (19). Normally the generic verb tao 'make' is used in this sense. However, if the speakers would like to specify the causation, it may be replaced by other action verbs, such as pare 'to slaughter' or game 'to hit'. The adjective bases always require causation to be expressed separately by a specific verb, such as the example in (20)a. This is confirmed by the ill-formed construction in (20)b. A construction as such implies that the events profiled in a causativized construction are arranged into separate components that each be expressed with a specific verb; the lexical verb expresses the causation and $p a$-verb expresses the affected event. The two verbs form a cohesive unit, thus no noun phrase (NP) may intervene between them. Therefore, $(20) \mathrm{c}$ is ungrammatical. The SVC in this regard is confirmed by the position of the negator boe 'not' after the two verbs, indicating that it negates the whole events. The list of adjective bases for $p a$-is presented in (21) below.

rèngu (tao) pa-madhe kahibi èèna

3PL make CAUS-die goat DIST.SG

'They cause the goat die'
a. nèngu tao pa-manii aj'u sèra 3SG make CAUS-thin wood DIST.PL 'He makes the logs thin'
b. nèngu *pa-manii aj'u sèra 3SG CAUS-thin wood DIST.PL
c. *nèngu tao aj’u sèra pa-manii
3SG make wood DIST.PL CAUS-thin
d. nèngu tao pa-manii boe aj'u sèra 3SG make CAUS-thin not wood DIST.PL 'He does not make the logs thin'

(21) Adjective bases for $p a-$

\begin{tabular}{|c|c|c|c|}
\hline (ana) iiki & 'small' & pa-ana iiki & to make $\mathrm{X}$ small \\
\hline aаpa & 'bad' & ра-аapa & to make $\mathrm{X}$ bad \\
\hline$b a b^{\prime} a$ & 'short, shallow' & $p a-b a b^{\prime} a$ & to shorten \\
\hline$b e^{\prime} a$ & 'good' & pa-be'a & to make $\mathrm{X}$ better \\
\hline bhèla & 'wide' & pa-bhèla & to widen \\
\hline dèbho & 'big (wood)' & pa-dèbho & to make $\mathrm{X}$ big \\
\hline kapai & 'big, large' & pa-kapai & to make $\mathrm{X}$ big \\
\hline kobo & 'narrow' & pa-kobo & to make $X$ narrow \\
\hline ma'aa & 'thick' & $p a-m a ' a a$ & to thicken \\
\hline madhera & 'long, tall' & pa-madhera & to lengthen \\
\hline manii & 'thin' & pa-manii & to make $X$ thin \\
\hline marèma & 'deep' & pa-marèma & to deepen \\
\hline
\end{tabular}




\section{Periphrastic Constructions}

Periphrastic constructions are constructions in which the $p a$-derived verb appears in the subordinate clause denoting result state of the causee, while the causation is expressed by a lexical verb in the main clause. These two clauses are tightly integrated in which the causing event in the main clause requires the result state to be expressed explicitly. The bases for this type of construction are typically adjectives. The constructions with the adjective bases may occur in the form of SVC, like (22)a, or of the periphrastic construction, like (22)b. This implies that the causative meaning is provided by the construction, but not realized by a lexical item (Foley, 2010:85). Unlike the causative constructions with SVCs, in periphrastic constructions a noun phrase intervene between the lexical verb expressing the causation and the $p a$-derived verb indicating the result state. The $p a$-derived verb occurs after the undergoer resulting in a biclausal construction. The two clauses cannot be broken up into two independent clauses, which suggests that the position of the $p a$-derived verb is an implicature of the event structure in the construction in that it expresses the process of the change of state. The ill-formedness of the example in (22)c confirms that the construction can never be an independent clause. The negator is more acceptable in the periphrastic construction (22)d, and not in any position of the verbs in the SVC (22)e.
a. èdhi sai pa-ana.iiki nèngu
1PL.in chop CAUS-child.small 3SG
'We cut it into small'
b. èdhi sai nèngu pa-ana.iiki
1PL.in chop 3SG CAUS-child.small
'We cut it into small'
c. *nèngu pa-ana.iiki
d. èdhi sai boe
1PL.in chop not
nèngu pa-ana.iiki
'We do not cut it into small'
e. èdhi sai (*boe) pa-ana.iiki (*boe $)$ nèngu
1PL.in chop not CAUS-child.small not 3SG

\section{CONCLUSION}

This paper has shown that causativization with the prefix $p a$ - results in three types of constructions profiling the causative events. Single verb constructions indicate that the causing event and the result state are expressed by the fusion of the prefix and the base. The SVCs and the periphrastic constructions suggest that Dhao causative allows the causing event to be expressed with a separate component from the resulting state. The causing event is profiled by an overt lexical verb and the integration of the prefix $p a$ - and the base denotes a process leading to a change of state of an entity. While the SVCs do not allow noun phrases to intervene between the two verbs, the periphrastic construction allows the pa-derived verbs to occur in a subordinate clause position. In that sense, however, the two clauses cannot be broken up into independent clauses indicating that the causative meaning is constructional. 


\section{NOTE}

*This paper has been presented at the Congress of Indonesian Linguistics Society in 2016 at Udayana Univeristy, Bali. The similar topic has also been presented in the 8th Austronesian and Papuan Languages and Linguistics (APPL8) conference, May 13-14, 2016, SOAS University of London under the title: Causative Prefix pa- and Serial Verb Constructions in Dhao.

\section{REFERENCES}

Aikhenvald, A. Y. (2006). Serial Verb Constructions in Typological Perspective. In A. Y. Aikhenvald \& R. M. W. Dixon (Eds.), Serial Verb Constructions a Cross-Linguistic Typology. Oxford, U.K.; New York: Oxford University Press. Retrieved from http://site.ebrary.com/id/10167528

Balukh, J. I. (to appear). A Grammar of Dhao, A Minority Language in Eastern Indonesia (PhD. Thesis). Leiden University.

Balukh, J. I. (2015a). Personal Pronouns in Dhao in Eastern Indonesia. Linguistik Indonesia, $33(2), 101-120$.

Balukh, J. I. (2015b). The Notion of "Adjective" in Dhao A Language Spoken in Eastern Indonesia. Wacana, 16(1), 42-79.

Balukh, J. I. (2016). Causative Prefix pa-and Serial Verb Constructions in Dhao, A Language in Eastern Indonesia. Presented at the 8th Austronesian and Papuan Languages and Linguistics (APPL8) conference, May 13-14, 2016, SOAS University of London. Retrieved from http://www.slideshare.net/pkaustin/apll8-balukh-slides

Blust, R. (2013). The Austronesian Languages. Canberra: Asia-Pacific Linguistics.

Dixon, R. M. W. (2012). Basic Linguistic Theory: Further Grammatical Topics (Vol. 3). Oxford; New York: Oxford University Press.

Foley, W. A. (2010). Events and Serial Verb Constructions. In M. Amberber, B. Baker, \& M. Harvey (Eds.), Complex Predicates: Cross-Linguistic Perspectives on Event Structure (pp. 79-109). Cambridge etc: Cambridge University Press.

Grimes, C. E. (2010). Hawu and Dhao in Eastern Indonesia. In M. Klamer \& M. Ewing (Eds.), East Nusantara, Typological and Areal Analyses (pp. 251-280). Canberra: Pasific Linguistics.

Haspelmath, M. (2016). The Serial Verb Construction: Comparative Concept and CrossLinguistic Generalizations, 17(3), 291-318.

Jonker, J. C. G. (1903). Iets Over de Taal van Dao. In Album-Kern; Opstellen Geschreven Ter Eere van Dr. H. Kern (pp. 85-89). Leiden: E. J. Brill.

Kulikov, L. I. (2001). Causatives. In M. Haspelmath (Ed.), Language Typology and Language Universals: An International Handbook (Vol. 2, pp. 886-898). Walter de Gruyter.

Shibatani, M. (1976). The Grammar of Causative Constructions: A Conspectus. In M. Shibatani (Ed.), The Grammar of Causative Constructions (Vol. 6, pp. 1-40). Academic Press. 
Jermy I. Balukh

Shibatani, M., \& Pardeshi, P. (2001). The Causative Contimuum. In M. Shibatani (Ed.), The Grammar of Causation and Interpersonal Manipulation (pp. 85-126). Amsterdam etc: Benjamins.

Walker, A. T. (1982). A Grammar of Sawu. Jakarta: Badan Penyelenggara Seri NUSA, Universitas Atma Jaya. 